\title{
Evaluation of Correlation between Acid Degree Value and Peroxide Value in Lipolysis of Control and Iron Fortified Caprine Milk Cheeses during 4 Months Storage
}

\author{
Aftab Siddique, Young W. Park* \\ Georgia Small Ruminant Research and Extension Center, Fort Valley State University, The University System of Georgia, \\ Fort Valley, GA, USA \\ Email: *parky@fvsu.edu
}

How to cite this paper: Siddique, A. and Park, Y.W. (2019) Evaluation of Correlation between Acid Degree Value and Peroxide Value in Lipolysis of Control and Iron Fortified Caprine Milk Cheeses during 4 Months Storage. Open Journal of Animal Sciences, 9, 1-11.

https://doi.org/10.4236/ojas.2019.91001

Received: October 29, 2018

Accepted: December 17, 2018

Published: December 20, 2018

Copyright $\odot 2019$ by authors and Scientific Research Publishing Inc. This work is licensed under the Creative Commons Attribution International License (CC BY 4.0).

http://creativecommons.org/licenses/by/4.0/

c) (i) Open Access

\begin{abstract}
Elevation of acid degree values (ADV) and peroxide value (POV) indicates deterioration of nutritional and sensory qualities of dairy products during storage. Iron fortification in bovine milk cheeses in relation to lipolytic parameters and their correlations have been studied, while no such studies have been reported on caprine milk cheeses. The objectives of this study were to evaluate levels of $\mathrm{ADV}$ and POV of iron fortified [regular ferrous sulfate (RFS) and large microencapsulated ferrous sulfate (LMFS)] goat milk Cheddar cheeses compared to those of non-fortified control cheese (CC) and their correlations. Three batches of 3 types (CC, RFS and LMFS added) of goat milk cheeses were manufactured and stored at two temperatures $\left(4^{\circ} \mathrm{C}\right.$ and $-18^{\circ} \mathrm{C}$ ) for 0,2 and 4 months. Iron was supplemented to RFS and LMFS cheeses by $8.23 \mathrm{~g}$ and $9.03 \mathrm{~g}$ per $9 \mathrm{~kg}$, respectively. ADV and POV were determined using standard methods of examining dairy products (Richardson, 1985) and AOCS (1975) procedures. Results showed that ADV values for CC, RFS and LMFS cheeses for 0 and 4 month storage at $4^{\circ} \mathrm{C}$ were: $0.67,0.73$, $0.64 ; 1.24,1.78,1.58$, respectively, indicating significant $(\mathrm{P}<0.05)$ elevations occurred in ADV for all three cheeses during 4 months storage. The cheese samples at 4 months storage showed significantly $(P<0.05)$ higher peroxide values compared to 0 and 2 month stored ones. The samples stored at refrigeration temperature $\left(4^{\circ} \mathrm{C}\right)$ revealed slightly more lipid oxidation than those stored at frozen temperature $\left(-18^{\circ} \mathrm{C}\right)$. Significant $(\mathrm{P}<0.05)$ elevations in POV for all goat cheeses stored for 4 months and slight increases in POV at higher temperature implies that the longer time and higher temperature storage can elevate the rate of lipid oxidation in goat milk Cheddar cheeses.
\end{abstract}


Correlations ( $\mathrm{r}$ ) between $\mathrm{ADV}$ and POV for the pooled data of three types of the caprine cheeses across storage periods were significant $(\mathrm{P}<0.01)$, while $\mathrm{r}$ values of CC cheeses alone were negative. It was concluded that significant correlations exist between extents of lipolysis and lipid oxidation in the caprine milk Cheddar cheeses during 4 months storage.

\section{Keywords}

Caprine Milk Cheese, Storage, Iron Fortification, ADV, POV, Correlation

\section{Introduction}

Quality of dairy products has been evaluated by various analytical methods. Lipolysis is the hydrolysis of lipids catalyzed by lipase enzymes, which has been a major dairy industry problem due to its implication of rancid flavor defect in milk, cheese and other dairy products [1]. Flavor deterioration resulted from lipolysis of dairy products has caused serious industry problems in storage stability and consumer acceptability [2] [3]. Lipolysis of goat milk cheeses has been estimated by acid degree value (ADV), acid value, and free fatty acid concentration, while lipid oxidation of dairy goat products can be determined by peroxide value, thiobarbuturic acid value (TBA) [1] [4].

Numerous biochemical and physical changes can occur in dairy products during manufacturing, distribution and storage processes due to ripening and degradation of nutrients in the products [1] [4]. Lipolysis and proteolysis are two major processes in dairy products ripening controlled by a variety of chemical, physical, microbiological, textural and rheological changes which take place under controlled environmental conditions [1] [4] [5] [6] [7] [8].

Sensory and flavor qualities of dairy products are significantly influenced by levels of peptides, amino acids and free fatty acids resulting from proteolysis and lipolysis [9] [10]. Proteolysis is the most important biochemical event, which gives a major impact on flavor and texture of most cheese varieties and other fermented dairy products [1] [4] [7] [11]. The rate of protein degradation is highly associated with the accessibility of proteolytic enzymes to the dairy product substrates, which is governed by the structure and configuration of the protein matrix of fermented dairy products such as cheese and yogurt [1]. Volatile compounds produced by lipolysis and proteolysis play major roles in flavor and sensory properties of yogurts [12] [13].

There are differences in lipolytic characteristics between goat and cow milk, due to the differences in fat moiety of the two species [1] [5]. Lipolysis and lipid oxidation are influenced by many factors, including free fatty acids, lipolytic microorganisms and enzymes, temperature, storage time, oxygen concentration, moisture content, antioxidant or pro-oxidant, etc. [1] [4] [14]. It has been shown that lipolyzed or rancid flavors are positively correlated to the levels of free fatty acid and short chain fatty acid contents. The presence of large amounts of free 
acids also can facilitate the rate of lipid oxidation [14].

Acid degree value (ADV) and peroxide value (POV) are two important indices for evaluation of lipid oxidation and lipolysis of food products. Elevation of POV or ADV during storage indicates deterioration of nutritional and sensory qualities of dairy products. Fortification of iron in milk and dairy products is desired due to the deficiency of iron in milk of many dairy species including cow and goats. Iron fortification in bovine milk cheeses in relation to lipolytic parameters and their correlations have been studied, while few such studies have been reported on caprine milk cheeses. Therefore, the objectives of this study were to: 1 ) determine acid degree value (ADV) and peroxide value (POV) of control and iron fortified caprine milk cheeses stored at two temperatures $\left(4^{\circ} \mathrm{C}\right.$ and $-18^{\circ} \mathrm{C}$ ) for 0,2 and 4 months, and 2) evaluate correlation coefficients between ADV and POV of the experimental goat cheeses in relation to the extents of lipolysis and lipid oxidation of the products.

\section{Materials and Methods}

\subsection{Preparation of Control and Iron Fortified Caprine Milk Cheddar Cheeses}

Goat milk Cheddar cheeses were manufactured in three batches for CC, RFS and LMFS cheeses each using the standard procedure of cow Cheddar cheese processing [15]. A $94.625 \mathrm{~L}$ (25 gallons) of goat milk were pasteurized and processed in a sixty gallon $(188 \mathrm{~L})$ size vat pasteurizer (Kusel Equipment Co., Watertown, WI) after pasteurization at $63^{\circ} \mathrm{C}$ for $30 \mathrm{~min}$. The milk was cooled to $31.1^{\circ} \mathrm{C}$, and 4.16 grams of lyophilized Direct Vat Set culture (R-704, Chr. Hansen's laboratory, Inc. Hoersholm, Denmark) was dissolved in deionized water and uniformly added to the cheese vat (Kusel Equipment Co. Watertown, WI), and agitated slowly for one hour. Thirty-five $\mathrm{ml}$ of single strength Chymax rennet (Chr. Hansen's laboratory, Inc. Hoersholm, Denmark) was added and stopped agitation for $30-45$ min for coagulation. The cheese curd was cut by wire curd knives $(1 / 2$ " $\times 1 / 2$ " $\times 3 / 4$ ") (Kusel Equipment Co. Watertown, WI). Ten minutes after cutting, curds were cooked by gradual increase in temperature $\left(1^{\circ} \mathrm{C}\right.$ every 5 minutes) to $39^{\circ} \mathrm{C}$ for 30 minute. After cooking the curds, whey was drained, and cheese curds were stacked by two sides in the vat for Cheddaring process by turning over the curds every $15 \mathrm{~min}$ for 3 times. Table salt and $0.8 \mathrm{gm}$ of food grade regular ferrous sulfate $\left(\mathrm{FeSO}_{4} \cdot 7 \mathrm{H}_{2} \mathrm{O}\right.$; Fisher Scientific, Fair lawn, NJ, USA) and $0.90 \mathrm{gm}$ of 700 - 800-micron medium particle size non-hydrogenated fat microencapsulated ferrous salt (Dr. Paul Lohmann Inc. Islandia, NY, USA) were added for iron fortification of the two experimental cheeses using the modified method of Arce and Ustunol [16]. The non-Fe fortified control and two Iron fortified cheese curds were hooped and pressed using a cheese press (Kusel Equipment Co., Watertown, WI) at 50 psi overnight. The pressed cheese was cut, placed in plastic pouches (Koch Inc. Kansas City, MO) and vacuum packaged (Koch Co. Kansas City, MO), and stored at $4^{\circ} \mathrm{C}$ and $-18^{\circ} \mathrm{C}$ for storage 
treatments.

\subsection{Analysis of Basic Nutrients}

\subsubsection{Moisture}

Moisture content for all samples in triplicates was analyzed by laboratory oven drying for 24 hours at $105^{\circ} \mathrm{C}$ [17]. Moisture content of samples was determined by subtracting dry matter weight from the original total fresh sample weight.

\subsubsection{Ash}

The ash content of cheese samples was determined by using an AOAC procedure [17]. Two grams of cheese sample were weighed into chemically cleaned crucibles, then the crucibles were placed in a muffle furnace at $550^{\circ} \mathrm{C}$ for eight hrs for complete ashing. After ashing, the crucibles containing ash samples were placed in desiccators to cool to room temperature, then the weight of ash measured with an analytical balance. The ash content was calculated by the following formula:

$$
\operatorname{Ash}(\% \text {, wet basis })=\frac{\text { Weight of } \operatorname{ash}(g) \times 100}{\text { Weight of cheese sample }(\mathrm{g})}
$$

\subsubsection{Protein}

The protein content was determined using a CEM Fastrac II analyzer (CEM cooperation, Mt. Laurel, NJ, USA), which is equipped with NMR technology, where the absorption of electromagnetic radiation in the radio-frequency region to measure $\mathrm{N}-\mathrm{C}$ bonds in protein molecules of the cheese samples. The total protein content of the samples was assayed in triplicate.

\subsubsection{Fat}

The fat content of cheese samples was determined using the Babcock procedure [17]. Nine-gram shredded cheese samples were placed into Babcock Paley cheese bottles. Ten $\mathrm{mL}$ of hot $\left(60^{\circ} \mathrm{C}\right)$ deionized water was added to the bottle, and thoroughly mixed the samples were allowed to cool down to room temperature. Fifteen $\mathrm{mL}$ of sulfuric acid was added in portion-wise manner $(8,4$ and $3 \mathrm{~mL})$ by swirling each time after careful addition. The bottles were shaken on a mechanical shaker for at least 5 minutes, and then place in a $60^{\circ} \mathrm{C}$ centrifuge for $5 \mathrm{mi}$ nutes at $600 \mathrm{rpm}$. The bottles were removed from the water bath at $57^{\circ} \mathrm{C}$, and dried quickly. The fat was measured immediately from the bottom of the lower meniscus to the highest point of upper meniscus of the graduated neck of the bottle.

\subsection{Physico-Chemical Analysis}

\subsection{1. pH}

Ten gr of shredded cheese sample and $20 \mathrm{~mL}$ of distilled water were placed in Waring blender cup and blended for $2 \mathrm{~min}$. The cheese sample slurry was then transferred to smaller beaker, and $\mathrm{pH}$ was measured in triplicate using a Fisher Scientific pH meter (Accumet AR10 pH Meter; Fisher Scientific, Fair Lawn, NJ, 
USA).

\subsubsection{Acid Degree Value (ADV)}

ADV was determined according to the procedure of Richardson [18]. Ten grams of shredded cheese samples were placed into a Babcock bottle, along with $10 \mathrm{~mL}$ of BDI reagent and mixed thoroughly, then the bottles were placed in a gentle boiling water bath for approximately $15-20 \mathrm{~min}$. The bottles were agitated after $5 \mathrm{~min}$, again after $10 \mathrm{~min}$ in the bath, and bottles were then allowed to remain in the boiling water for $5 \mathrm{~min}$ to ensure clean fat separation. The sample Babcock bottles were then be placed into a centrifuge for $1 \mathrm{~min}$, then water was added to bring up the fat column well within the graduated portion of the neck of bottle and centrifuged again for $1 \mathrm{~min}$. After centrifugation, the bottles were placed in the water bath $\left(57^{\circ} \mathrm{C}\right)$ for $5 \mathrm{~min}$. When the fat was separated in the graduated neck of the bottle, $1 \mathrm{~mL}$ (or $1 \mathrm{gr}$ ) of fat was transferred to an Erlenmeyer flask. The fat was dissolved in $5 \mathrm{ml}$ fat solvent, and 5 drops of $1 \%$ phenolphthalein added to Erlenmeyer flasks. The samples were then titrated with $0.1 \mathrm{~N}$ potassium hydroxide until the faint color was changed to persist at the endpoint. The ADV value of each sample was calculated by the following formula:

$$
\mathrm{ADV}=\frac{(\mathrm{mL} \mathrm{KOH} \text { for sample }-\mathrm{mL} \mathrm{KOH} \text { for blank }) \times \mathrm{N} \times 100}{\text { Weight of Fat }}
$$

where $\mathrm{N}=$ Normality of $\mathrm{KOH}(0.1 \mathrm{~N})$.

\subsubsection{Peroxide Value (POV)}

Peroxide value was analyzed using the AOCS procedure [19]. The lipids of cheese samples were extracted using Folch et al. [20] method. Five grams of previously extracted fat sample was weighed into a $250 \mathrm{~mL}$ Erlenmeyer flask. Thirty milliliters of acetic acid-chloroform solution $(3: 2 \mathrm{v} / \mathrm{v})$ was added to each sample, and contents swirled until dissolved. A $0.5 \mathrm{~mL}$ saturated potassium iodide was added to each sample, and shaken for one min. Thirty milliliters of distilled water was added to each sample, and the sample was shaken vigorously. One $\mathrm{mL}$ starch solution (1\%) was added to each sample. The sample flask was titrated with $0.01 \mathrm{~N}$ sodium thiosulfate until the bottom layer appeared milky, which indicated the end point.

The peroxide value was calculated using the following equation:

$\operatorname{POV}($ milliequiv. of Peroxide $/ 1000 \mathrm{~g}$ sample $)=\frac{[\text { titration of sample }(\mathrm{mL})-\text { titration of blank }(\mathrm{mL})] \times 0.01 \mathrm{~N} \times 1000}{\text { Sample weight }(\mathrm{g})}$

\section{Results and Discussion}

\section{1. $\mathrm{pH}$}

The mean $\mathrm{pH}$ values of CC, RFS and LMFS cheeses for 0,2 and 4 month storage were: $5.30,5.22,5.26 ; 5.21,5.20,5.19 ; 5.16,5.14,5.15$, respectively (Table 1 ). These data clearly indicated that $\mathrm{pH}$ values of all three cheeses were decreased as the storage time extended. The decreases in $\mathrm{pH}$ may suggest that more acid such 
Table 1. Comparison of mean $\mathrm{pH}$ values in control and two iron fortified goat milk cheeses during four months storage.

\begin{tabular}{cccc}
\hline \multirow{2}{*}{ Cheese type } & Month 0 & Month 2 & Month 4 \\
\cline { 2 - 4 } & Mean \pm SD & Mean \pm SD & Mean \pm SD \\
\hline CC & $5.30^{\mathrm{ax}} \pm 0.03$ & $5.21^{\mathrm{ay}} \pm 0.62$ & $5.16^{\mathrm{ax}} \pm 0.14$ \\
RFS & $5.22^{\mathrm{bx}} \pm 0.05$ & $5.20^{\mathrm{ax}} \pm 0.63$ & $5.14^{\mathrm{by}} \pm 0.12$ \\
LMFS & $5.26^{\mathrm{bx}} \pm 0.05$ & $5.19^{\mathrm{by}} \pm 0.67$ & $5.15^{\mathrm{ay}} \pm 0.12$ \\
\hline
\end{tabular}

CC: Control cheese; RFS: Regular ferrous sulfate cheese; LMFS: Large microencapsulated ferrous sulfate cheese.

as lactic acid, organic acids and free fatty acids are generated in the aged cheese samples as the storage period advanced. The acid degree values in Table 2 also showed the increasing trend in all the experimental goat cheese samples at the 4 months of storage period. However, beyond 4 months storage, the decreases in $\mathrm{pH}$ may not continue due to the buffering components such as ammonia group would be generated from the ripening cheese proteins for further ripening of the cheese products.

\subsection{ADV (Acid Degree Value)}

$\mathrm{ADV}$ is a measure of the amount of free fatty acids generated in a food sample for a certain period of time. The ADV of fresh control cheese and two types of iron fortified cheese samples for 0,2 , and 4 months are summarized in Table 2. The ADV values at 0 and 4 month at $4^{\circ} \mathrm{C}$ for control, RFS and LMFS cheeses were: $0.67,0.73,0.64 ; 1.24,1.78,1.58$, respectively, indicating that significant $(\mathrm{P}$ $<0.01$ ) elevations occurred in ADVs of all three cheeses after 4 months storage, while the differences in ADV between cheese types were not significant at 2 months of storage. The effect of storage temperature $\left(4^{\circ} \mathrm{C}\right.$ and $\left.-18^{\circ} \mathrm{C}\right)$ was also significant $(\mathrm{P}<0.05)$ especially at 4 month storage (Table 2 and Table 3$)$. Increases in ADV values in this study are in agreement with the previous reports on goat milk cheeses [1] [5]. The 2-way interaction effects were significant on $A D V$ values by storage period $x$ temperature $(P<0.01)$ and cheese type $x$ storage period $(\mathrm{P}<0.05)$. These ADV results imply that storage time and temperature, and their interactions had significant influence on lipolysis of the experimental goat cheeses. ADV values of LMFS and RFS cheeses were higher than those of control cheese at 4 months storage, which may indicate that the added iron may have increased the amount of free fatty acids compared to the non-iron fortified control cheese. The 3-way interaction of cheese type $\times$ storage time $\times$ temperature effect was not significant on ADV, but significant $(\mathrm{P}<0.05)$ on $\mathrm{pH}$ and POV in this study (Table 3).

\subsection{Peroxide Value (POV)}

Peroxide value is the number of milliequivalents of peroxide per kilogram of fat samples, where hydroperoxide is the primary product of lipid oxidation. POV 
Table 2. Comparison of ADV values between control and two iron fortified goat cheeses under different storage period and temperature treatments.

\begin{tabular}{cccccccc}
\hline \multirow{2}{*}{ Cheese type } & \multirow{2}{*}{ Temp } & \multicolumn{2}{c}{0 month } & \multicolumn{2}{c}{2 month } & \multicolumn{2}{c}{4 month } \\
\cline { 2 - 7 } & & Mean & SD & Mean & SD & Mean & SD \\
\hline CC & 4 & $0.67^{\text {by }}$ & 0.03 & $0.66^{\text {by }}$ & 0.04 & $1.24^{\text {ax }}$ & 0.031 \\
& -18 & $0.81^{\text {ax }}$ & 0.03 & $0.79^{\text {bx }}$ & 0.03 & $0.78^{\text {by }}$ & 0.02 \\
RFS & 4 & $0.73^{\text {bx }}$ & 0.03 & $0.74^{\text {bx }}$ & 0.03 & $1.78^{\text {ax }}$ & 0.02 \\
& -18 & $0.75^{\text {bx }}$ & 0.02 & $0.76^{\text {abx }}$ & 0.02 & $0.88^{\text {ay }}$ & 0.03 \\
\multirow{2}{*}{ LMFS } & 4 & $0.64^{\text {ax }}$ & 0.10 & $0.58^{\text {ay }}$ & 0.03 & $1.58^{\text {abx }}$ & 0.08 \\
& -18 & $0.63^{\text {bx }}$ & 0.03 & $0.65^{\text {bx }}$ & 0.02 & $1.52^{\text {ay }}$ & 0.03 \\
\hline
\end{tabular}

CC: Control Cheese; RFS: Regular ferrous Sulphate Cheese; LMFS: Large Microencapsulated Ferrous Sulphate Cheese; ${ }^{a, b, c}$ Means with different superscripts within a same column are significantly different $(\mathrm{P}<$ $0.05)$; ${ }^{x, y, z}$ Means with different superscripts within a same row are significantly different $(P<0.05)$.

Table 3. Analysis of variance (F-value) on effects of cheese type, storage temperature, storage time, and their interactions on $\mathrm{ADV}, \mathrm{POV}$ and $\mathrm{pH}$ values of goat cheeses.

\begin{tabular}{ccccc}
\hline Parameters & DF & ADV & POV & pH \\
\hline CT & 2 & 1.79 & 0.03 & 1.57 \\
BA & 2 & 2.90 & 1.40 & 0.87 \\
SP & 2 & $46.75^{* *}$ & $4.53^{*}$ & 0.59 \\
ST & 1 & $4.58^{*}$ & 0.16 & 0.00 \\
CT $\times$ ST & 2 & 0.95 & 4.23 & 0.01 \\
CT $\times$ SP & 2 & $4.75^{*}$ & 0.09 & $2.51^{*}$ \\
ST $\times$ SP & 2 & $25.19^{* *}$ & 1.87 & 0.22 \\
CT $\times$ SP $\times$ ST & 4 & 1.23 & $2.16^{*}$ & $2.40^{*}$ \\
\hline
\end{tabular}

CT: Cheese type; BA: Batch; ST: Storage Temperature; SP: Storage Period; ${ }^{*} \mathrm{P}<0.05$ or ${ }^{*} \mathrm{P}<0.001$.

values of the control and iron fortified goat milk Cheddar cheeses during four months of storage are shown in Table 4 and Figure 1.

There were significant $(\mathrm{P}<0.05)$ differences in POV between storage periods for the control and iron fortified goat Cheddar cheeses (Table 4 and Figure 1). Cheeses stored at frozen temperature $\left(-18^{\circ} \mathrm{C}\right)$ at 4 month storage showed slightly low peroxide value than those samples stored at refrigerated temperature $\left(4^{\circ} \mathrm{C}\right)$, suggesting that the cheese samples stored at higher temperature may have a tendency to cause more lipid oxidation than those stored at lower temperature. Samples at 4 month storage had significantly $(\mathrm{P}<0.05)$ higher peroxide values, compared to 0 and 2 month stored ones, implying that the rate of lipid oxidation can increase as the storage time extended for the goat milk Cheddar cheeses. However, the POV values observed in this study were still below the critical value of peroxide less than 1 milliequivalent peroxide/1000 g sample for fresh fat [21], indicating that the experimental goat Cheddar cheeses had no appreciable lipolysis up to 4 months storage, so that the quality of the cheeses would be acceptable for consumption. 
Table 4. Comparison of mean peroxide values (milliequiv. of Peroxide/1000 g sample) in goat milk Cheddar cheeses during four months of storage at 4 and $-18^{\circ} \mathrm{C}$.

\begin{tabular}{cccccccc}
\hline \multirow{2}{*}{ Cheese type } & & \multicolumn{2}{c}{0 month } & \multicolumn{2}{c}{2 months } & \multicolumn{2}{c}{4 months } \\
\cline { 2 - 7 } & & Mean & SD & Mean & SD & Mean & SD \\
\hline Control Cheese & 4 & $0.92^{\mathrm{bx}}$ & 0.03 & $0.92^{\mathrm{bx}}$ & 0.93 & $1.05^{\mathrm{ax}}$ & 0.03 \\
& -18 & $0.93^{\mathrm{bx}}$ & 0.03 & $0.94^{\mathrm{bx}}$ & 0.03 & $1.04^{\mathrm{ax}}$ & 0.02 \\
\multirow{2}{*}{ RFS Cheese } & 4 & $0.94^{\mathrm{bx}}$ & 0.04 & $0.95^{\mathrm{ay}}$ & 0.06 & $1.03^{\mathrm{ax}}$ & 0.02 \\
& -18 & $0.96^{\mathrm{bx}}$ & 0.04 & $0.96^{\mathrm{bx}}$ & 0.04 & $1.03^{\mathrm{ax}}$ & 0.03 \\
\multirow{2}{*}{ LMFS Cheese } & 4 & $0.93^{\mathrm{bx}}$ & 0.05 & $0.93^{\mathrm{bx}}$ & 0.90 & $1.05^{\mathrm{ax}}$ & 0.05 \\
& -18 & $0.91^{\mathrm{bx}}$ & 0.09 & $0.93^{\mathrm{ax}}$ & 0.07 & $1.03^{\mathrm{ay}}$ & 0.07 \\
\hline
\end{tabular}

${ }^{a, b, c} \mathrm{Means}$ with different superscript within a same row are significantly different $(\mathrm{P}<0.05)$; ${ }^{\mathrm{x}, \mathrm{y}, \mathrm{z}} \mathrm{Means}$ with different superscript within a same column are significantly different $(\mathrm{P}<0.05)$.

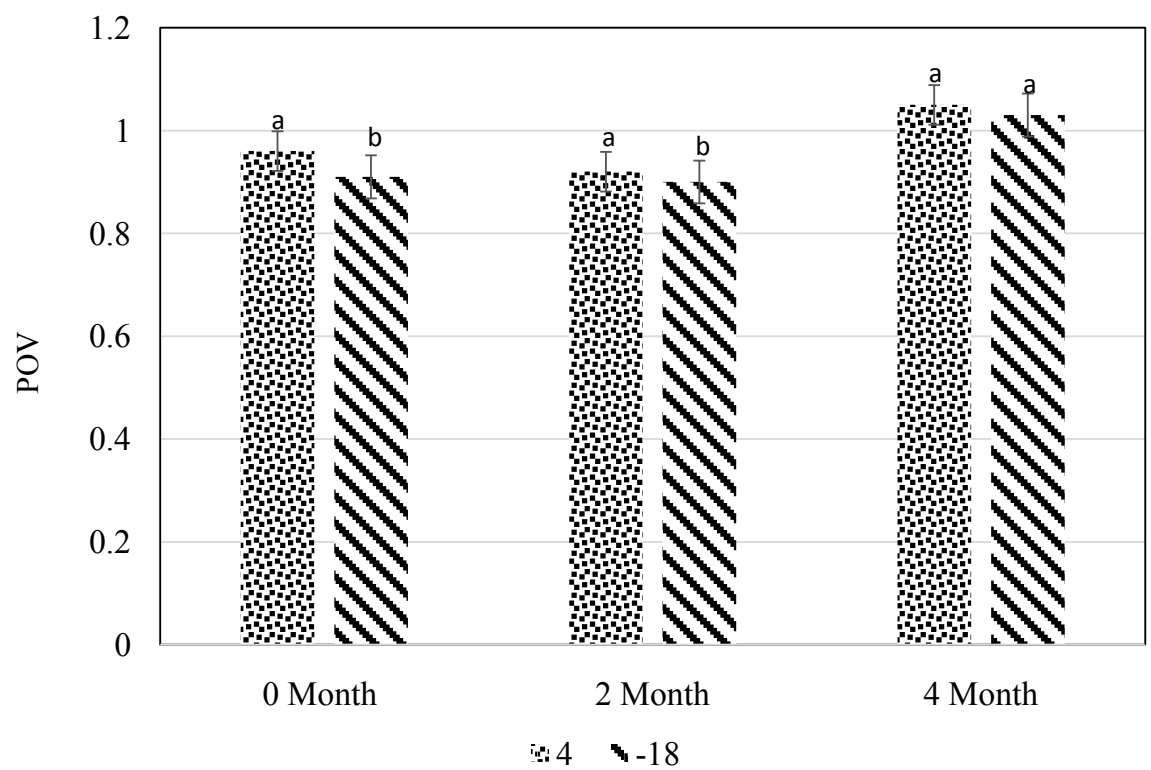

Figure 1. Comparison of mean peroxide values of control and iron fortified goat Cheddar cheese among three different storage periods at $4^{\circ} \mathrm{C}$. ${ }^{\mathrm{a}, \mathrm{b}} \mathrm{Bars}$ with different letters are significantly different $(\mathrm{P}<0.05)$.

\subsection{Correlation between ADV and POV}

It is generally known that ADV is the index for lipolysis and POV depicts for lipid oxidation of animal food samples. In the study of correlation(r) between ADV and POV in dairy products, it would be expected that a positive strong relationship would exist between the two parameters in the aged cheese or other dairy products. The $r$ values between ADV and POV for the pooled data of three types of goat cheeses across storage period and across storage temperature were significant $(\mathrm{P}<0.05$ or $\mathrm{P}<0.001)$ (Table 5$)$. The outcomes of the present study revealed that the ADVs had significant positive correlations with the POVs of the three types of goat Cheddar cheeses stored both $4^{\circ} \mathrm{C}$ and $-18^{\circ} \mathrm{C}$ for 4 months storage period. These results may suggest that there were significant correlations 
Table 5. Correlations between levels of POV and ADV across storage periods in control and two iron fortified goatmilk Cheddar cheeses.

\begin{tabular}{cccc}
\hline Parameter & Cheese Type & ADV $4^{\circ} \mathrm{C}$ & $\mathrm{ADV}-18^{\circ} \mathrm{C}$ \\
\hline \multirow{2}{*}{ POV } & CC & $0.584^{*}$ & -0.260 \\
& RFS & $0.820^{* *}$ & $0.730^{* *}$ \\
& LMFS & $0.706^{* *}$ & $0.735^{* *}$ \\
\hline
\end{tabular}

CC: Control Cheese; RFS: Regular ferrous sulphate; LMFS: Large microencapsulated ferrous sulphate; ${ }^{*}$ Significant at $5 \%$ level $(\mathrm{P}<0.05)$; ${ }^{*}$ Significant at $1 \%$ level $(\mathrm{P}<0.01)$.

between lipolysis and lipid oxidation in the experimental control and iron fortified goat milk Cheddar cheeses.

Increases in lipid oxidation can cause undesirable sensory properties such as flavor, odor and texture [21]. The increased rate of lipid oxidation have been taken place as the storage period advanced in our experimental goat cheeses, where previous reports have shown that lipid oxidation is influenced by various storage conditions, including oxygen, exposure to light, temperature, moisture, and the amount of unsaturated fatty acids [1] [22] [23].

\section{Conclusions}

Lipolysis and lipid oxidation are important indices to assess organoleptic quality and consumer acceptability of dairy products including goat milk cheeses. Elevation of POV and ADV values at different storage conditions indicates the deterioration of nutritional and sensory qualities of dairy products.

In this study, ADV values were significantly increased in control and iron fortified cheeses after 4 months storage, indicating that significant lipolysis occurred during 4 months storage of the caprine Cheddar cheese products. However, the differences in ADV between cheese types were not significant at 2 months storage. The effect of storage temperature was also significant. In regard to lipid oxidation, significant differences were found in POV between control and the two iron fortified goat cheeses at different storage periods and temperatures, implying that storage period and temperature elevated the rate of lipid oxidation. Cheese samples stored for 4 month had significantly higher POV, compared to 0 and 2 month stored ones. Correlations (r) between ADV and POV for the pooled data of the control and two types iron fortified caprine Cheddar cheeses across storage periods were significant. The results of our study showed that significant correlations exist between the levels of ADV and POV in the experimental goat milk Cheddar cheeses.

It was concluded that lipolysis and lipid oxidation were generally highly correlated in the experimental goat milk cheeses. Further studies are desirable to determine for longer storage periods and more storage temperature treatments for evaluation of ADV and POV in caprine milk products.

\section{Conflicts of Interest}

The authors declare no conflicts of interest regarding the publication of this paper. 


\section{References}

[1] Park, Y.W. (2001) Proteolysis and Lipolysis of Goat Milk Cheese. Journal of Dairy Science, 84, E84-E92. https://doi.org/10.3168/jds.S0022-0302(01)70202-0

[2] Allen, J.C. and Wrieden, W.L. (1982) Influence of Milk Protein on the Lipid Oxidation in Aqueous Emulsion. I. Casein, Whey Protein and Lactalbumin. Journal of Dairy Research, 49, 239. https://doi.org/10.1017/S0022029900022342

[3] Fox, P.F. and Guinee, T.P. (2013) Cheese Science and Technology. Chapter 17. In: Park, Y.W. and Haenlein, G.F.W., Eds., Milk and Dairy Products in Human Nutrition, Wiley-Blackwell Publishers, Oxford, UK, 357-386. https://doi.org/10.1002/9781118534168.ch17

[4] Fox, P.F. (1989) Proteolysis during Cheese Manufacture and Ripening. Journal of Dairy Science, 72, 1379-1400. https://doi.org/10.3168/jds.S0022-0302(89)79246-8

[5] Jin, Y.K. and Park, Y.W. (1995) Effects of Aging Time and Temperature on Proteolysis of Commercial Goat Milk Cheeses Produced in the United States. Journal of Dairy Science, 78, 2598-2608. https://doi.org/10.3168/jds.S0022-0302(95)76888-6

[6] Salji, J.P. and Kroger, M. (1981) Proteolysis and Lipolysis in Ripening Cheddar Cheese Made with Conventional Bulk Starter and with Frozen Concentrated Direct-to-the-Vat Culture. Journal of Food Science, 46, 1345. https://doi.org/10.1111/j.1365-2621.1981.tb04170.x

[7] Bertola, N.C., Bevilacqaua, A.E. and Zaritzky, N.E. (1992) Proteolytic and Rheological Evaluation of Maturation of Tybo Argentino Cheese. Journal of Dairy Science, 75, 3273-3281. https://doi.org/10.3168/jds.S0022-0302(92)78102-8

[8] Park, Y.W. and Jin, Y.K. (1998) Proteolytic Patterns of Caciotta and Monterey Jack Hard Goat Milk Cheeses as Evaluated by SDS-PAGE and Densitometric Analyses. Small Ruminant Research, 28, 263-272. https://doi.org/10.1016/S0921-4488(97)00092-8

[9] Deeth, H.C. and Fitz-Gerald, C.H. (1976) Lipolysis in Dairy Products: A Review. Australian Journal of Dairy Technology, 31, 53-64.

[10] Igoshi, K., Kaminogawa, S. and Yamauchi, K. (1986). Profiles of Proteinase in Gouda-Type Cheese. Journal of Dairy Science, 69, 2018-2026. https://doi.org/10.3168/jds.S0022-0302(86)80631-2

[11] Baek, Y.J. and Lee, B.H. (2009) Probiotics and Prebiotics as Bioactive Components in Dairy Products. In: Park, Y.W., Ed., Bioactive Components in Milk and Dairy Products, Wiley-Blackwell Publishers, Ames, IA and Oxford, England, 287-312.

[12] Ulbert, F. (1991) Headspace Gas Chromatographic Estimation of Some Yoghurt Volatiles. J. AOAC, 74, 630-634.

[13] Guler, Z. and Park, Y.W. (2011) Characteristics of Physico-Chemical Properties, Volatile Compounds and Free Fatty Acid Profiles of Commercial Set-Type Turkish Yoghurts. Open Journal of Animal Sciences, 1, 1-9. https://doi.org/10.4236/ojas.2011.11001

[14] Fennema, O.R. (2008) Food Chemistry. 3rd Edition, Marcel Dekker, New York, 225-319.

[15] Park, Y.W. and Guo, M.R. (2006) Goat Milk Products: Processing Technology, Types and Consumption Trends. In: Park, Y.W. and Haenlein, G.F.W., Eds., Handbook of Milk of Non-Bovine Mammals, Blackwell Publishers, Ames, IA and Oxford, England, 59-106. https://doi.org/10.1002/9780470999738.ch4

[16] Arce, A. and Ustunol, Z. (2018) Effect of Microencapsulated Ferrous Sulfate Particle Size on Cheddar Cheese Composition and Quality. Journal of Dairy Science, 101, 
1-9. https://doi.org/10.3168/jds.2017-13952

[17] AOAC (1995) Official Methods of Analysis of the AOAC International. 16th Edition, AOAC International, Arlington, Virginia, 489.

[18] Richardson, G.H., Ed. (1985) Page 327. In: Standard Methods for the Examination of Dairy Products, 15th Edition, American Public Health Association, Washington DC.

[19] AOCS (1975) Official Methods and Recommended Practices of the American Oil Chemists' Society. American Oil Chemists' Society, Champaign, IL.

[20] Folch, J., Lees, M. and Sloane Stanley, G.H. (1957) A Simple Method for the Isolation and Purification of Total Lipides from Animal Tissues. Journal of Biological Chemistry, 226, 497-509.

[21] Mortensen, G., Sørensen, J. and Stapelfeldt, H. (2002) Comparison of Peroxidevalue Methods Used for Semi Hard Cheeses. Journal of Agricultural and Food Chemistry, 50, 5007-5011. https://doi.org/10.1021/jf0200220

[22] Andersen, C.M., Wold, J.P. and Mortensen, G. (2006) Light-Induced Changes in Semi-Hard Cheese Determined by Fluorescence Spectroscopy and Chemometrics. International Dairy Journal, 16, 1483-1489. https://doi.org/10.1016/j.idairyj.2005.11.014

[23] Nouira, W., Park, Y.W., Guler, Z. and Terrill, T. (2011) Comparison of Free Fatty Acid Composition between Low-Fat and Full-Fat Goat Milk Cheeses Stored for 3 Months under Refrigeration. Open Journal of Animal Sciences, 1, 17-23.

https://doi.org/10.4236/ojas.2011.12003 